\title{
Detection of Enterobacteriaceae, antimicrobial susceptibility, and virulence genes of Escherichia coli in canaries (Serinus canaria) in northeastern Brazil ${ }^{1}$
}

\author{
Antonio Jackson F. Beleza ${ }^{2 *}$ (D), William C. Maciel $^{2}$, Arianne S. Carreira ${ }^{2}$, \\ Windleyanne G.A. Bezerra ${ }^{2}$, Cecilia C. Carmo ${ }^{2}$, Alexandre Havt ${ }^{3}$, Fernanda C. Gaio ${ }^{2}$ \\ and Régis S.C. Teixeira ${ }^{2}$
}

\begin{abstract}
Beleza A.J.F., Maciel W.C., Carreira A.S., Bezerra W.G.A., Carmo C.C., Havt A., Gaio F.C. \& Teixeira R.S.C. 2019. Detection of Enterobacteriaceae, antimicrobial susceptibility, and virulence genes of Escherichia coli in canaries (Serinus canaria) in northeastern Brazil. Pesquisa Veterinária Brasileira 39(3):201-208. Setor de Estudos Ornitológicos, Faculdade de Veterinária, Universidade Estadual do Ceará, Av. Paranjana 1700, Fortaleza, CE 60740-903, Brazil. E-mail: jacksonxand@gmail.com

This study aimed to verify the presence of members from the Enterobacteriaceae family and determine antimicrobial susceptibility profiles of the isolates in canaries bred in northeastern Brazil; in addition, the presence of diarrheagenic Escherichia coli (DEC) and avian pathogenic Escherichia coli (APEC) was also verified in these birds. Samples were collected during an exhibition organized by the Brazilian Ornithological Federation in July 2015 in Fortaleza, Brazil. A total of 88 fecal samples were collected and submitted to pre-enrichment step using buffered peptone water, followed by enrichment with the following broths: brain-heart infusion, Rappaport-Vassiliadis, and Selenite-Cystine. Subsequently, aliquots were streaked on MacConkey, brilliant green and salmonella-shigella agar plates. Colonies were selected according to morphological characteristics and submitted to biochemical identification and antimicrobial susceptibility tests with disk-diffusion technique. E. coli strains were evaluated for the presence of eight DEC genes and five APEC genes through conventional polymerase chain reaction (PCR) screening. The most frequent species observed were Pantoea agglomerans (25\%), Serratia liquefaciens (12.5\%), and Enterobacter aerogenes $(9.1 \%)$. A single rough strain of Salmonella enterica subsp. enterica was identified in one sample (1.1\%). High resistance rates to amoxicillin (78.7\%) and ampicillin $(75.4 \%)$ were identified. Polymyxin B (9.8\%), gentamycin (6.6\%), and enrofloxacin (6.6\%) were the most efficient antibiotics. The total number of multidrug-resistant strains (isolates resistant to more than three antimicrobial classes) was 23 (37.7\%). Four E. coli strains were tested for the virulence genes, and two were positive for APEC virulence genes: one strain was positive for iutA and the other for $h l y F$. In conclusion, canaries in northeastern Brazil participating in exhibitions may present Salmonella spp., Escherichia coli and other enterobacteria in the intestinal microbiota with antimicrobial resistance. These results indicate that, although the E. coli strains recovered from canaries in this study have some virulence genes, they still do not fulfill all the requirements to be considered APEC.
\end{abstract}

INDEX TERMS: Enterobacteriaceae, antimicrobial susceptibility, virulence genes, Escherichia coli, canaries, Serinus canaria, northeastern Brazil, antibiogram, diarrheagenic, APEC, Belgian canaries, bacterioses.

\footnotetext{
${ }^{1}$ Received on August 31, 2018.

Accepted for publication on November 9, 2018.

${ }^{2}$ Laboratório de Estudos Ornitológicos, Faculdade de Veterinária, Universidade Estadual do Ceará (UECE), Av. Paranjana 1700, Fortaleza, CE 60740-903, Brazil. *Corresponding author: jacksonxand@gmail.com

${ }^{3}$ Laboratório de Toxinologia Molecular, Universidade Estadual do Ceará (UECE), Rua Alexandre Baraúna 994, Rodolfo Teófilo, Fortaleza, CE 60430-160.
}

RESUMO.- [Detecção de enterobactérias, sensibilidade antimicrobiana e genes de virulência de Escherichia coli em canários belgas (Serinus canaria) da região Nordeste do Brasil.] 0 objetivo deste trabalho foi verificar a presença de enterobactérias e determinar o perfil de sensibilidade aos antimicrobianos dos isolados oriundos de 
canários belgas criados em cativeiro do Nordeste do Brasil, adicionalmente verificou-se a presença de Escherichia coli diarreiogênicas (DEC) e E. coli patogênica aviária (APEC) nesses animais. A colheita das amostras ocorreu durante uma exposição de canários belgas organizada pela Federação Ornitológica do Brasil (FOB), em julho de 2015, na cidade de Fortaleza, Ceará, Brasil. Um total de 88 amostras de fezes foram coletadas e submetidas a pré-enriquecimento utilizando água peptonada, caldo de enriquecimento Brain Heart Infusion, Rappaport-Vassiliadis e Selenito-Cistina. Fez-se triagem em placas de ágar MacConkey, Verde Brilhante e ágar Salmonella Shigella. As colônias foram selecionadas e submetidas à identificação bioquímica e susceptibilidade antimicrobiana. Estirpes de Escherichia coli foram avaliadas quanto a presença de 8 genes de virulência de DEC e cinco de APEC por reação em cadeia da polimerase convencional (PCR). As enterobactérias encontradas com maior frequência foram Pantoea agglomerans (25\%), Serratia liquefaciens $(12,5 \%)$ e Enterobacter aerogenes (9,1\%). Uma única estirpe de Salmonella enterica subsp. enterica (rugosa) esteve presente em um dos isolados $(1,1 \%)$. Altos percentuais de resistência foram encontrados para dois antibióticos: amoxicilina $(78,7 \%)$ e ampicilina $(75,4 \%)$. Polimixina B $(9,8 \%)$, gentamicina $(6,8 \%)$ e enrofloxacina $(6,5 \%)$ foram os antibióticos com melhor eficiência. 0 total de estirpes multirresistentes (a mais de três classes de antimicrobianos) foi de 23 (37,7\%). Das quatro estirpes de E. coli isoladas, duas foram positivas para os genes de APEC, sendo uma estipe para o gene iss e outra para os genes iutA e hlyF. Portanto, canários belgas criados em cativeiro no Brasil que participam de exposições podem apresentar Salmonella spp., Escherichia coli e outras enterobactérias em sua microbiota intestinal com resistência antimicrobiana. Estes resultados indicam que as estirpes de $E$. coli isoladas de canário belga no presente estudo apresentam alguns, mas não todos, genes de virulência para serem caracterizadas como E. coli patogênica para aves (APEC).

TERMOS DE INDEXAÇ̃̃O: Enterobactérias, sensibilidade antimicrobiana, genes de virulência, Escherichia coli, antibiograma, diarreiogênica, APEC, canários belgas, Serinus canaria, bacterioses.

\section{INTRODUCTION}

Currently, the Belgian canary (Serinus canaria), order Passeriformes, family Fringillidae, is one of the birds most sought by breeders worldwide, esteemed for its smooth and harmonious singing and beautiful colors, as well as for being very docile and of easy, low-cost maintenance (Mantel 2005, Arnaiz-Villena et al. 2012). The legal breeding of birds can serve as an important mechanism in environmental conservation and protection (Camargo et al. 2010); therefore, canary breeding, in addition to being a hobby, can be an activity that discourages the illegal search for wild birds.

Infections caused by bacteria of the family Enterobacteriaceae are common in birds of the Passeriformes order; however, they are considered secondary, and the presence of predisposing factors is necessary to trigger diseases in birds (Guimarães 2007). Several pathogens belonging to the Fringillidae family have been reported causing different diseases in birds (canaries, chaffinches, common linnets, goldfinches, greenfinches, red crossbills), namely, Escherichia coli, Salmonella spp.,
Citrobacter sp., Yersinia pseudotuberculosis, and Klebsiella spp. (Macwhirter 1994, Dorrestein 1997, 2009, Guimarães 2007).

Escherichia coli is a commensal bacterium commonly found in the intestinal microbiota of homeothermic animals. However, pathogenic strains of this species are capable of causing intestinal and extraintestinal diseases in humans, mammals, and birds, resulting in significant economic losses to breeders and serious public health problems (Koneman et al. 2001, Kaper et al. 2004, Croxen \& Finlay 2010, Bélanger et al. 2011). Studies addressing bacterial strains that cause septicemia in humans and birds have demonstrated that the genome can show a wide variety due to the presence of plasmids, phages, and mobile elements, thus the occurrence of these elements in pathogens such as E. coli is common (Mokady et al. 2005). In addition, similar virulence factors have been commonly described in strains of $E$. coli isolated in humans and in avian pathogenic E. coli (APEC), thus demonstrating their zoonotic potential (Ewers et al. 2007, Moulin-Schouleur et al. 2007, Smith et al. 2007, Tivendale et al. 2010, Bélanger et al. 2011).

Salmonellosis is an important bacterial disease in canaries and other birds raised as pets (Harrington Junior et al. 1975, Herikstad et al. 2002). This disease is caused by bacteria of the genus Salmonella, a pathogen known for its zoonotic potential, which can lead to high mortality (Kanashiro et al. 2002, Soncini 2002). Infection usually develops asymptomatically, and the birds become subclinical hosts, continuously or intermittently eliminating the agent in their feces (Flammer 1999). Knowledge about the occurrence and distribution of Salmonella spp. in domestic and wild animals is essential to list possible hosts that may be responsible for the transmission of this agent (D'aout et al. 2001).

There are few scientific studies addressing Enterobacteriaceae in birds of the Passeriformes order bred in captivity in the literature, with most of the research focusing on the poultry industry. There is also lack of available information on the epidemiological role of canaries kept as pets regarding the epidemiology of E. coli, Salmonella spp. and other enterobacteria, and their susceptibility/antibacterial resistance profiles. In this context, this study aims to verify the presence of members of the Enterobacteriaceae family, determine the antimicrobial susceptibility profile of the isolates from Belgian canaries (Serinus canaria) bred in captivity in northeastern Brazil, and analyze the presence of strains of diarrheagenic E. coli (DEC) and avian pathogenic E. coli (APEC).

\section{MATERIALS AND METHODS}

Sampling. Fecal samples of Belgian canaries (Serinus canaria), bred for the purpose of exhibition of type or color, collected from the bottom of cages were used in this study. The canaries, which belonged to 44 breeders from several states of northeastern Brazil (Alagoas, Bahia, Ceará, Maranhão, Piauí, Paraíba, Pernambuco, Rio Grande do Norte, and Sergipe), were competing in a bird show. The event was attended by 1448 birds (1255 and 193 canaries competing for type and color, respectively) that were individually housed in cages ( $32 \mathrm{~cm}$ long, $22 \mathrm{~cm}$ wide, $21 \mathrm{~cm}$ high). The cages were made of stainless steel, equipped with suitable perches, and easy to clean. The birds were fed a mixture of seeds (birdseed, millet, turnip) and water ad libitum. The bottom of the cages was coated with white sulfite paper sheets, which were removed daily along with the birds' feces and overlapped feed. Feed and water were changed and their containers were cleaned daily. Microbiological analysis 
was performed using material obtained from 440 different cages of canaries participating in the exhibition. One paper sheet containing canary feces was collected from each of the cages. They were then packed in sterile plastic bags and sent in isothermal boxes containing recyclable ice to the Laboratory of Ornithological Studies, College of Veterinary Medicine (LABEO-FAVET), at the State University of Ceará (UECE) for further processing. From each white sulfite paper sheet, $2 \mathrm{~g}$ of feces were collected for microbiological analysis. Each sample was defined as a pool of biological material (feces) from the bottom of five cages of the same breeder. Thus, a total of 88 samples were submitted to microbiological analysis, and each breeder provided sufficient material for the investigation of two samples.

Microbiological processing of Enterobacteriaceae. The methodology described in Sousa et al. (2010) was used for the isolation of enteropathogens. Upon arrival at the laboratory, the feces were processed in stages in which the temperature and incubation time of the samples in the oven were standardized at $37^{\circ} \mathrm{C}$ for 24 hours. In the first stage, the feces from each sample were collected using a spatula, conditioned in $10 \mathrm{~mL}$ of $1 \%$ buffered peptone water, and then incubated. Subsequently, aliquots were transferred to enrichment broths: $1 \mathrm{~mL}$ to Brain-heart Infusion (BHI) and Selenite-Cystine (SC) and 0.1mL to Rappaport-Vassiliadis (RV), respectively. After incubation, they were streaked on brilliant green (BG), Salmonella-Shigella (SS) and/or MacConkey (MC) agar plates, and then reincubated.

Distinct colonies were collected from the plates and inoculated into tubes containing Triple-sugar-iron (TSI) agar, Lysine iron (LIA) agar, and Sulfide-indole-motility (SIM) medium. After the incubation period, the following biochemical tests were applied for confirmation of enterobacteria: lysine decarboxylation, ornithine descarboxylation, methyl red, urea, Simmons citrate, arginine decarboxylase, malonate, Voges-Proskauer, carbohydrates fermentation, lactose, sucrose, mannitol,, arabinose, raffinose, dulcitol, adonitol, inositol, and sorbitol (Holt \& Bergey 1994, Koneman et al. 2012). Samples suspected for Salmonella spp. were submitted to the rapid serum agglutination test using a polyvalent ' $O$ ' (somatic) antiserum. For confirmation of suspicious samples, isolates were stored in nutrient agar and sent to a reference laboratory (Fiocruz) for serotyping.

Sensitivity profile of Enterobacteriaceae (antimicrobial susceptibility test). Enterobacteriaceae isolates were submitted to the Kirby-Bauer disc diffusion method, and the zones of inhibition were read according to the standards of the Clinical and Laboratory Standards Institute-CLSI (2014). After streaking the solution (sample), disks with the antibiotics were equally distributed on a plate containing Müller-Hinton agar, and the zones of inhibition were measured after incubation at $37^{\circ} \mathrm{C}$ for $24 \mathrm{~h}$. Antibiotics of the following pharmacological classes at the following concentrations

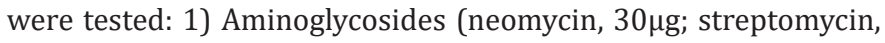
$10 \mu \mathrm{g}$ and gentamicin, $10 \mu \mathrm{g}$ ); 2) Sulfonamide (sulfonamide, $300 \mu \mathrm{g}$ and sulfazotrim (sulfamethoxazole + trimethoprim), 25 $\mu \mathrm{g}$ ); 3) Beta

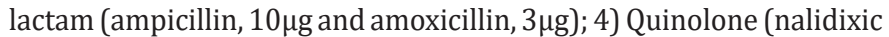

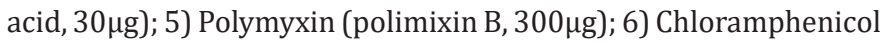

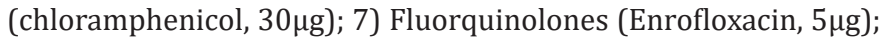
8) Tetracycline (tetracycline, $30 \mu \mathrm{g}$ ). For this test, the ATCC 25922 Escherichia coli strain was used as control. Multidrug resistance (MDR) was considered when the strains were resistant to at least three classes of antimicrobials (Magiorakos et al. 2012).

Detection of diarrheagenic Escherichia coli (DEC) and avian pathogenic Escherichia coli (APEC). For molecular analysis, the isolated $E$. coli strains that were maintained in nutrient agar were reactivated in $\mathrm{BHI}$ broth, incubated at $37^{\circ} \mathrm{C}$ for 24 hours, and streaked on MacConkey agar to confirm purity of strain. Two to three colonies were collected from each plate, placed in tubes containing $1 \mathrm{~mL}$ of $0.5 \%$ Triton X-100, vortexed for $15 \mathrm{~s}$, and boiled for $20 \mathrm{~min}$ at $94^{\circ} \mathrm{C}$. The tubes were then centrifuged at $10.000 \mathrm{rpm}$ for $10 \mathrm{~min}$ at $4^{\circ} \mathrm{C}$. The supernatant containing DNA was quantified by spectrophotometry using a NanoDrop Spectrophotometer 2000 (Thermo Scientific, Wilmington, USA). For the molecular diagnosis of DEC, the DNA samples were submitted to polymerase chain reaction (PCR) screening. The presence of eight virulence genes from five pathotypes were assessed as follows: genes stx 1 (348pb) and st $x 2(584 \mathrm{pb})$ for identification of Shiga-Toxina-producing Escherichia coli (STEC); eltB (508 pb) and estA (147 pb) for enterotoxigenic E. coli (ETEC); eaeA (881 pb) for enteropathogenic E. coli (EPEC); ipa $\mathrm{H}$ (483 pb) for enteroinvasive E. coli (EIEC); aatA (630 pb) and aaiC (215 pb) for enteroaggregative E. coli (EAEC) (Taniuchi et al. 2012). The strains EAEC 042, EHEC 0157: H7, EIEC 0124, EPEC 2348/69, and ETEC H10407 were used as positive controls for the reactions. The strains were also submitted to detection of five minimal predictors of APEC virulence genes: iroN (Salmochelin receptor), iss (serum resistant), hlyF (toxin encoding), omp T (episome-encoded outer membrane protease), and iutA (ferric aerobactin receptor). Although there is no consensus in the scientific literature on which genes would define an APEC strain, the findings of Johnson et al. (2008) were used in this study, which showed that APEC isolates obtained from organs with lesions of birds clinically diagnosed with colibacillosis had, on average, four of the five genes considered predictive for this pathotype. DNA extraction was performed using the boiling method (Lima et al. 2013). PCR screening was performed using a GoTaqGreen kit (Promega) and 0.2uM primers in a MyCycler ${ }^{\mathrm{TM}}$ Thermal Cycler (Biorad, CA, USA) system according to the following protocol: $95^{\circ} \mathrm{C}$ for $15 \mathrm{~min}$; 40 cycles at $95^{\circ} \mathrm{C}$ for $30 \mathrm{~s}, 57^{\circ} \mathrm{C}$ for $30 \mathrm{~s}$ and $72^{\circ} \mathrm{C}$ for $1 \mathrm{~min}$, followed by $72^{\circ} \mathrm{C}$ for $10 \mathrm{~min}$. The amplified products were submitted to agarose gel electrophoresis, stained with $2 \%$ ethidium bromide, and photographed using the ChemicDoc ${ }^{\mathrm{TM}}$ XRS 112 (Biorad, CA, USA) transilluminator system.

\section{RESULTS}

Isolated bacteria. Of the 88 fecal samples investigated, 40 were negative for Enterobacteriaceae (45.4\%). The studied microorganisms tested positive in 48 cases (54.5\%); however, it is worth noting that, in some of the samples, more than one bacterial species was detected, which resulted in a total of 61 isolates. Pantoea agglomerans was the bacterium with the highest frequency of isolation $(22 / 61)$ with $25 \%$, followed by Serratia liquefaciens (11/61) with $12.5 \%$, and Enterobacter aerogenes $(8 / 61)$ with $9.1 \%$. The least frequently isolated pathogens were Enterobacter cloacae (5/61) with $5.7 \%$, Encherichia coli (4/61) with 4.5\%, Hafnia alvei (3/61) and Cronobacter sakazakii (3/61) with 3.4\% each, Serratia rubidae (2/61) with $2.3 \%$, Salmonella enterica subsp. enterica (rough) (1/61), Shigella sonnei (1/61), and Klebsiella pneumoniae (1/61) with $1.1 \%$ each (Table 1 ).

Antimicrobial resistance. Table 2 shows the results of the antimicrobial susceptibility test. The antibiotics that showed the best efficiency were polimixin B $(9.8 \%)$, gentamicin $(6.6 \%)$, and enrofloxacin (6.6\%), and those to which the total bacterial isolates showed greater resistance were amoxicillin (78.7\%), ampicillin (75.4\%), streptomycin (45.9\%), and sulfonamides (42.6\%). Results of the 22 Pantoea agglomerans isolated strains showed that higher frequency of bacterial resistance occurred in relation to amoxicillin ( $\mathrm{n}=18)$, ampicillin 
$(\mathrm{n}=16)$, and sulfonamides $(\mathrm{n}=4)$. Among the other three most frequently occurring bacterial species (Serratia liquefaciens, Enterobacter aerogenes, and Enterobacter cloacae, respectively), high absolute frequency of amoxicillin-resistant strains was also observed. Among the four Escherichia coli isolated strains, the highest frequency of resistant bacteria was observed when streptomycin $(\mathrm{n}=3)$ was tested; for other antibiotics, resistance frequency did not exceed one occurrence. The only Salmonella enterica subsp. enterica (rough) strain isolated was resistant to amoxicillin and streptomycin. Among the 61 strains isolated in this study, only seven (11.5\%) showed no resistance to any of the classes of antibiotics tested. Twenty-three strains $(37.7 \%)$ showed resistance to $\geq 3$ antibiotic classes, that is, MDR condition. Occurrence of resistance to all 12 antibiotics tested was observed in only one isolate $(1.6 \%)$ (Table 3), belonging to the Enterobacter aerogenes species.

Detection of diarrheagenic Escherichia coli (DEC) and avian pathogenic Escherichia coli (APEC). The four Escherichia coli strains isolated and screened by the PCR technique tested negative for all genes characteristic of

Table 1. Absolute and relative frequencies of Enterobacteriaceae isolated from fecal samples of Belgian canaries (Serinus canaria)

\begin{tabular}{lcc}
\hline \multicolumn{1}{c}{ Bacterium } & $\mathrm{n}$ & $\%$ \\
\hline Pantoea agglomerans & 22 & 25 \\
Serratia liquefaciens & 11 & 12.5 \\
Enterobacter aerogenes & 8 & 9.1 \\
Enterobacter cloacae & 5 & 5.7 \\
Escherichia coli & 4 & 4.5 \\
Hafnia alvei & 3 & 3.4 \\
Cronobacter sakazakii & 3 & 3.4 \\
Serratia rubidaea & 2 & 2.3 \\
Salmonella enterica subsp. enterica (rough) & 1 & 1.1 \\
Shiguella sonnei & 1 & 1.1 \\
Klebsiella pneumoniae & 1 & 1.1
\end{tabular}

DEC pathotypes. Regarding the search of APEC genes, only two isolates were positive: one detected for the iss gene and another for the iutA and $h l y F$ genes. In this search, it was verified that one isolate was presented with the iss gene and the other strain contained the iut $A$ and $h l y F$ genes; the other two cases were negative. Therefore, the APEC pathotype was not identified in this search.

\section{DISCUSSION}

Results of the present study showed that Belgian canaries host different bacterial species of the family Enterobacteriaceae that have commonly been reported in several scientific studies. Conzo et al. (1998) isolated and identified Klebsiella pneumoniae, Pantoae agglomerans, Enterobacter cloacae, among other species of bacteria in a survey of Enterobacteriaceae conducted with Belgian canaries raised in nurseries in Naples, southern Italy. Horn et al. (2015) detected Escherichia coli, Enterobacter spp., Klebsiella spp., Pantoea agglomerans, and Serratia spp. in cloacal swabs of Belgian canaries from breeders in the region of Fortaleza, Ceará state, Brazil. Giacopello et al. (2015) reported the occurrence of gram-negative bacteria such as Escherichia coli, Enterobacter cloacae, Cronobacter sakazakii, Pantoea agglomerans, among other species, in feces of canaries with signs of diseases originating from aviaries of amateur breeders in Sicily, southern Italy.

Pantoea agglomerans was the most prevalent enterobacterium in the present study. This bacterium has also been reported in other species of healthy birds kept in captivity (Santos et al. 2010). Despite being generally considered a microorganism harmless to the health of birds, in some circumstances, its presence can be harmful. Gerlach (1994) clarified that the birds are likely to be infected with this bacterium through consumption of seeds, and that feed containing a high concentration of this microorganism is considered toxic. Conzo et al. (1998) listed this pathogen as one among other isolated Enterobacteriaceae responsible for the mortality of offspring and embryos of Belgian canaries. According to Kirzinger et al. (2015), another aspect worth highlighting with respect to this bacterial species

Table 2. Absolute frequency of Enterobacteriaceae isolated from Belgian canaries (Serinus canaria) resistant to antibiotics

\begin{tabular}{|c|c|c|c|c|c|c|c|c|c|c|c|c|}
\hline $\begin{array}{l}\text { Bacterium (total number of } \\
\text { isolates) }\end{array}$ & AMO & AMP & NAL & TET & CLO & GEN & SUL & POL & NEO & ENR & SUT & STR \\
\hline Serratia liquefaciens (11) & 10 & 10 & 5 & 3 & 2 & - & 5 & 3 & 5 & - & 2 & 5 \\
\hline Enterobacter cloacae (5) & 5 & $4^{\mathrm{IR}}$ & - & - & - & - & 3 & - & - & - & - & 4 \\
\hline Escherichia coli (4) & 1 & 1 & 1 & 1 & - & - & 1 & - & - & 1 & 1 & 3 \\
\hline Serraria rubidaea (2) & 2 & 2 & - & - & 1 & - & 1 & 1 & - & - & 1 & 1 \\
\hline Salmonella enterica* (1) & 1 & - & - & - & - & - & - & - & - & - & - & 1 \\
\hline Shigella sonnei (1) & - & - & - & - & - & - & - & - & - & - & - & - \\
\hline Klebsiella pneumoniae (1) & 1 & $1^{1 \mathrm{IR}}$ & - & - & - & - & - & - & - & - & - & - \\
\hline Total number of & 49 & 46 & 17 & 9 & 8 & 4 & 26 & 6 & 15 & 4 & 10 & 28 \\
\hline
\end{tabular}

Enterobacteriaceae (61)

*Salmonella enterica subsp. enterica (rough), ${ }^{\mathrm{IR}}$ intrinsic resistance; $\mathrm{AMO}=$ Amoxicillin, $\mathrm{AMP}=\mathrm{ampicillin}, \mathrm{NAL}=$ nalidixic acid, TET = tetracycline, $\mathrm{CLO}=$ chloramphenicol, GEN = gentamicin, SUL = sulfonamides, POL = polymyxin B, NEO, neomycin, ENR = enrofloxacin, SUT = sulfazotrim (sulfamethoxazole + trimethoprim), STR = streptomycin. 
Table 3. Multidrug-resistant (MDR) enterobacteria isolated from Belgian canaries (Serinus canaria)

\begin{tabular}{cc} 
Number of classes of antibiotics & Number of resistant strains $(\%)^{*}$ \\
\hline 0 & $7(11.5)$ \\
2 & $20(32.8)$ \\
3 & $11(18.0)$ \\
4 & $8(13.1)$ \\
5 & $5(8.2)$ \\
6 & $3(4.9)$ \\
7 & $4(6.6)$ \\
8 & $2(3.3)$ \\
\end{tabular}

* The frequency obtained for each number of classes of antibiotics was the same when strains with and without intrinsic resistance were considered.

is that $P$ agglomerans performs important exchanges of pathogenicity-determining genetic materials in the colonization of the host with other members of the Enterobacteriaceae family, including species pathogenic to humans.

Serratia liquefaciens was the second most frequently isolated bacterium in this study. In the Passeriformes order, this bacterial species has previously been isolated from cloacal swabs of saffron finch (Sicalis flaveola) seized from illegal trade in the city of São Paulo, Brazil (Davies et al. 2016). In a study addressing enterobacteria in cardinals (Paroaria dominicana and Paroaria coronata) seized from illegal trade in Sao Paulo, Cunha et al. (2016) isolated this bacterial species from cloacal swabs. In both studies, the authors did not describe whether the birds were ill. Fudge (2001) reported that it is not common for this genus to cause disease, but that it can affect immunocompromised birds. In humans, this microorganism has been reported to cause popliteal artery aneurysm infection that had been previously healed in patients (Coelho et al. 2016), as well as urinary infections (Menezes et al. 2004).

Enterobacter aerogenes and Enterobacter cloacae are bacteria commonly isolated in clinically healthy birds; however, they may also cause primary or secondary infections in immunocompromised birds, and may act concurrently with parasites, viruses, or fungi (Fudge 2001, Joseph 2003). Gharieb et al. (2013) investigated bacteria in wild birds from various locations in Egypt and isolated E. aerogenes and E. cloacae. In humans, E. aerogenes and E. cloacae have been reported in hospitals as important opportunistic pathogens, causing sepsis in neonates (Akindolire et al. 2016, Köse et al. 2016, Boulos et al. 2017), nosocomial infection (Oliva-Menacho et al. 2016), and septicemia in health professionals (Jha et al. 2016).

In this study, only one sample tested positive for bacteria of the genus Salmonella, and it was not possible to identify the serotype, only of the subspecies enterica (rough). According to Dorrestein \& Vet Pathol (2003), this pathogen can cause high mortality in canaries; however, the birds from which the samples were collected showed no symptoms of salmonellosis. In Brazil, there are no published scientific reports showing positivity for Salmonella sp. in fecal samples or cloacal swabs from captive Belgian canaries. In free-living birds of the Passeriformes order, Dias et al. (2014) isolated Salmonella enterica in saffron finch (Sicalis flaveola) and in chestnut-capped blackbird (Chrysomus ruficapillus) captured near rice fields in southern Rio Grande do Sul state, Brazil. Previous studies conducted with Belgian canaries bred in captivity in other countries have also isolated this bacterial genus, with serotype Typhimurium as the most prevalent (Harrington Junior et al. 1975, Raidal 1998, Sánchez-Cordón et al. 2007, Madadgar et al. 2009, Giacopello et al. 2015), and obtained low frequency of isolation, corroborating the findings of the present study.

In the present study, 4.5\% (4/88) of the isolated samples were Escherichia coli strains. Similar results were found by Horn et al. (2015), who observed 3.6\% positivity in samples from apparently healthy Belgian canaries, but from cloacal swabs. In contrast, other studies have reported higher frequencies of $E$. coli in the Passeriformes order. In a survey of 50 fecal samples from cages where canaries with signs of disease belonging to amateur breeders were housed in Italy, Giacopello et al. (2015) found $62.0 \%$ positivity for this microorganism. Gaio (2017) observed that cloacal swabs from wild passerines from illegal trade also showed high percentage of E. coli (40.8\%). Therefore, it can be assumed that the environmental conditions and sanitary status to which passerines are subjected may influence the isolation rate of $E$. coli.

All four strains analyzed were negative for the DEC genes investigated, which indicates that the isolates assessed were free of eight important potential diarrheal genes in humans (Lopes et al. 2016). Some genes associated with the APEC pathotype were detected in two strains: one positive for the iss gene and another for the iutA and $h l y F$ genes. Although all these detected genes showed important virulence characteristics attributed to the APEC pathotype (Lynne et al. 2006, Chouikha et al. 2008, Johnson et al. 2008), none of the $E$. coli strains could be characterized as belonging to this pathotype, because they did not have all the necessary genes. However, it is important to emphasize that, according to Oliveira et al. (2015), pathogenic strains usually have two or more predictive genes for the APEC pathotype, whereas isolates with fewer than two genes are rarely pathogenic. In contrast, Johnson et al. (2008) state the need for at least four types of predictor genes to differentiate strains with pathogenic potential from commensal E. coli.

In the present study, some of the tested antibiotics showed high frequency of antimicrobial resistance. Amoxicillin was the antibiotic for which the strains presented greater resistance (78.7\%), followed by ampicillin (75.4\%), streptomycin (45.9\%), and sulfonamides (42.6\%). Data relative to antimicrobial resistance in strains from Belgian canary fecal samples are quite scarce in the scientific literature, and the few existing studies show divergent results. One of the few similarities observed refers to resistance associated with ampicillin, which has very often been present as one of the antibiotics with most serious resistance problems. Giacopello et al. (2015) also observed that the highest resistance in enterobacteria analyzed in canaries in Italy occurred with respect to amoxicillin (100\%), ampicillin (92.2\%), and streptomycin (61.2\%), and these detected rates show percentages higher than those found in the present study. Horn et al. (2015) reported percentage resistance rates of $55.7,54.1$, and $39.3 \%$ to sulfonamides, 
ampicillin, and tetracycline, respectively, in canaries bred in captivity in the municipality of Fortaleza, Ceará state, Brazil.

Some aspects should be considered when analyzing the resistance results found in this study. The first refers to the fact that not all cases of resistance occur due to an acquired condition; in some cases, bacteria manifest intrinsic resistance to some antibiotics, as in the case of ampicillin associated with Enterobacter aerogenes, Enterobacter cloacae, Hafnia alvei and Klebsiella pneumoniae (CLSI 2014) pathogens, which even after subtracting the cases of resistance associated with these bacteria, still remains the antibiotic that shows the second highest resistance occurrence in relation to Enterobacteriaceae. Regarding the case of MDR (37.7\%), the frequency found in this study was lower than that observed by Horn et al. (2015), who verified that $49.2 \%$ of the Enterobacteriaceae isolated were resistant to three or more of the antibiotics investigated. Nevertheless, it is worth mentioning that the analysis conducted by these researchers, as it has occurred in several other studies involving Passeriformes and birds of other species raised in captivity, did not consider, for the purpose of MDR calculations, the guidelines indicated by Magiorakos et al. (2012), in which the quantification of strains resistant to an antibiotic should be made considering the classes of antibiotics used. Regardless, the MDR frequency detected in strains isolated from canary samples in northeastern Brazil serves as an alert for breeders, because this fact can have negative consequences for animal health, considering that the occurrence of bacteria with high rates of resistant antimicrobials hinders infection treatment and contributes to increased therapeutic costs (Oliveira et al. 2012).

Currently, bacterial resistance is a public health issue. One of the most important facts that have led to the emergence of MDR strains is the excessive and inadequate use of antibiotics (Nascimento et al. 2003), either as prevention or for diseases without diagnosis. In this respect, it can be observed that veterinary guidance is not always followed or even sought by bird breeders. In addition, access to antimicrobials has been facilitated in veterinary drug stores recently. Another factor related to this matter refers to the direct contact between birds and breeders. Santos et al. (2010) states that this relationship allows the exchange of microorganisms with resistance genes.

\section{CONCLUSIONS}

Different enterobacteria were isolated in feces collected from Belgian canaries (Serinus canaria), and this seems to be the first report of bacteria of the genus Salmonella isolated from fecal samples of birds belonging to breeders from northeastern Brazil.

The high frequency of resistance that some of the isolated bacterial strains presented to some of the antimicrobials analyzed suggests the need for greater control of the use of these drugs in order to avoid possible future therapeutic difficulties in the fight against microorganisms affecting national bird breeding.

Acknowledgements.- The authors are grateful to the Laboratory of Ornithological Studies, College of Veterinary Medicine (LABEO-FAVET) of the State University of Ceará (UECE) and Laboratory of Molecular Toxicology (LTM) of the Federal University of Ceará (UFC), as well as to the Ceará Research Foundation (FUNCAP) for the financial support provided to this study.

Conflict of interest statement.- The authors declare no conflict of interest.

\section{REFERENCES}

Akindolire A.E., Tongo O., Dada-Adegbola H. \& Akinyinka 0. 2016. Etiology of early onset septicemia among neonates at the University College Hospital, Ibadan, Nigeria. J. Infect. Develop. Ctries 10(12):1338-1344. <http://dx.doi. org/10.3855/jidc.7830> <PMid:28036314>

Arnaiz-Villena A., Areces C. \& Ruiz-Del-Valle V. 2012. El origen de los canarios. Revta Ornitol. Práct. 53:3-11.

Bélanger L., Garenaux A., Harel J., Boulianne M., Nadeau E. \& Dozois C.M. 2011. Escherichia coli form animal reservoirs as a potential source of human extraintestinal pathogenic E. coli. Immunol. Med. Microbiol. 62(1):1-10. <http://dx.doi.org/10.1111/j.1574-695X.2011.00797.x><PMid:21362060>

Boulos A., Rand K., Johnson J.A., Gautier J. \& Koster M. 2017. Neonatal sepsis in Haiti. J. Trop. Pediatr. 63(1):70-73. <http://dx.doi.org/10.1093/tropej/ fmw077><PMid:27765888>

Camargo C.M.J., Camargo L.J.J. \& Sueiro R.F. 2010. A criação amadora de pássaros nativos e os danos ambientais à fauna do Mato Grosso do Sul. Atualidades Ornitológicas 155(3):56-61.

Conzo G., Menna L.F. \& Cerrone A. 1998. Enterobacteria infection in canaries (Serinus canaria) related bacterial food contamination (Compania). Selezione Vet. 8-9:717-723.

Coelho A., Lobo M., Martins V., Gouveia R., Sousa P., Campos J., Augusto R., Coelho N. \& Canedo A. 2016. Serratia liquefaciens infection of a previously excluded popliteal artery aneurysm. EJVES Short Reports 34:1-4. <http:// dx.doi.org/10.1016/j.ejvssr.2016.10.002> <PMid:28856323>

Chouikha I., Bree A., Moulin-Schouleur M., Gilot P. \& Germon P. 2008. Differential expression of iutA and ibeA in the early stages of infection by extra-intestinal pathogenic E. coli. Microbes Infect. 10(4):432-438. <http://dx.doi.org/10.1016/j.micinf.2008.01.002> <PMid:18403237>

Cunha M.P.V., Guimarães M.B., Davies Y.M., Milanelo L. \& Knöbl T. 2016. Bactérias gram-negativa em cardeais (Poroaria coronata e Poroaria dominicana) apreendidos do tráfico de animais silvestres. Braz. J. Vet. Res. Anim. Sci. 53(1):107-111. <http://dx.doi.org/10.11606/issn.1678-4456. v53i1p107-111>

Croxen M.A. \& Finlay B.B. 2010. Molecular mechanisms of Escherichia coli pathogenicity. Nat. Rev. Microbiol. 8(1):26-38.<http://dx.doi.org/10.1038/ nrmicro2265><PMid:19966814>

CLSI 2014. Performance Standards for Antimicrobial Susceptibility Testing. CLSI document M100-S24, Twenty-Fourth Informational Supplement. Clinical and Laboratory Standards Institute, Wayne.

D’aout J.Y., Maurer J. \& Baley J.S. 2001. Salmonella species, p.141-178. In: Doyle M.P. \& Beuchat L.R. (Eds), Food Microbiology: fundamentals frontiers. ASM Press, Madison.

Davies Y.M., Guimarães M.B., Milanelo L., Oliveira M.G.X., Gomes V.T.M., Azevedo N.P., Cunha M.P.V., Moreno L.Z., Romero D.C., Christ A.P.G., Sato M.I.Z., Moreno A.M., Ferreira A.J.P., Sá L.R.M. \& Knöbl T. 2016. A survey on gram-negative bacteria in saffron finches (Sicalis flaveola) from illegal wildlife trade in Brazil. Braz. J. Vet. Res. Anim. Sci. 53(3):286-294.<http:// dx.doi.org/10.11606/issn.1678-4456.bjvras.2016.109042>

Dias P.A., Wilsmann D.E., Heinen J.G., Corsini C.D., Calabuig C. \& Timm C.D. 2014. Primeiro relato de Salmonella enterica e Campylobacter spp. isolados de Garibaldi (Chrysomus ruficapillus) e Canário-da-terra (Sicalis flaveola) silvestres. Revta Inst. Adolfo Lutz 73(4):368-371.

Dorrestein G.M. 1997. Passerines, p.867-885. In: Altrnan R.B., Clubb S.L., Dorrestein G.M. \& Quesenberry K. (Eds), Avian Medicine and Surgery. W.B. Saunders, Philadelphia.

Dorrestein G.M. \& Vet Pathol D. 2003. Diagnostic approaches and management of diseases in captive passerines. Semin. Avian Exotic Pet Med.12(1):1120. <http://dx.doi.org/10.1053/saep.2003.127881> 
Dorrestein G.M. 2009. Bacterial and parasitic diseases of passerines. Vet. Clin. N. Am., Exotic Anim. Pract. 12(3):433-451. <http://dx.doi.org/10.1016/j. cvex.2009.07.005><PMid:19732703>

Ewers C., Li G., Wilking H., Kiessling S., Alt K., Antáo E.M., Laturnus C., Diehl I., Glodde S., Homeier T., Böhnke U., Steinrück H., Philipp H.C. \& Wieler L.H. 2007. Avian pathogenic, uropathogenic, and newborn meningitiscausing Escherichia coli: how closely related are they? Int. J. Med. Microbiol. 297(3):163-176. <http://dx.doi.org/10.1016/j.ijmm.2007.01.003> $<$ PMid:17374506>

Fudge A.M. 2001. Diagnosis and treatment of avian bacterial diaseases. Semin. Avian Exotic Pet Med. 10(1):33-11. <http://dx.doi.org/10.1053/ saep.2001.19542>

Flammer K. 1999. Zoonosis acquired from birds, p.151-156. In: Fowler M.E. \& Miller R.E. (Eds), Zoo and Wild Animal Medicine: current therapy. W.B. Saunders, Philadelphia.

Gaio F.C. 2017. Isolamento, resistência e caracterização das cepas de Escherichia coli e Salmonella spp. em Psitacídeos presentes no centro de triagem de animais silvestres do Ceará. Master's Thesis, Postgraduate Program in Veterinary Science, Universidade Estadual do Ceará, Fortaleza, CE. 57p.

Gerlach H. 1994. Bacteria, p.949-983. In: Ritchie B.W., Harrinson G.J. \& Harrinson L.R. (Eds), Avian Medicine: principles and application. Wingers Publishing, Florida.

Giacopello C., Foti M., Fisichella V. \& Lo Piccolo F. 2015. Antibiotic-resistance patterns of Gram-negative bacterial isolates from breeder canaries (Serinus canaria domestica) with clinical disease. J. Exotic Pet. Med. 24(1):84-91. <http://dx.doi.org/10.1053/j.jepm.2014.12.009>

Guimarães M.B. 2007. Passeriformes, p.324-337. In: Cubas Z. S., Silva J.C.R. \& Catão-Dias J.L. (Eds), Tratado de Animais Selvagens: medicina veterinária. Roca, São Paulo.

Gharieb A., Abu-El-ezz R.M. \& Mohamad R.E. 2013. Prevalence of Enterobacteriacea in wild birds and humans at sharkia province; with special reference to the genetic relationship between E. coli and Salmonella isolates determined bby protein profile analysis. J. Am. Sci. 9(4):173-183.

Harrington Junior R., Blackburn B.O. \& Cassidy D.R. 1975. Salmonelosis in canaries. Avian Diseases 19(4):827-829. <http://dx.doi.org/10.2307/1589197> <PMid:1106388>

Herikstad H., Motarjemi Y. \& Tauxe R.V. 2002. Salmonella surveillance: a global survey of public health serotyping. Epidemiol. Infect. 129(1):1-8. <http://dx.doi.org/10.1017/S0950268802006842> <PMid:12211575>

Holt J. \& Bergey D.H. 1994. Bergey's Manual of Determinative Bacteriology. 9th ed. William and Wilkis, Baltimore. 787p.

Horn R.V., Cardoso W.M., Lopes E.S., Teixeira R.S.C., Albuquerque Á.H., Rocha-e-Silva R.C., Machado D.N. \& Bezerra W.G. 2015. Identification and antimicrobial resistance of members from the Enterobacteriaceae family isolated from canaries (Serinus canaria). Pesq. Vet. Bras. 35(6):552-556. <http://dx.doi.org/10.1590/S0100-736X2015000600011>

Johnson T.J., Wannemuehler Y., Doetkott C., Johnson S.J., Rosenberger S.C. \& Nolan L.K. 2008. Identification of minimal predictors of avian pathogenic Escherichia coli virulence for use as a rapid diagnostic tool. J. Clin. Microbiol. 46(12):3987-3996. <http://dx.doi.org/10.1128/JCM.0081608><PMid:18842938>

Joseph V. 2003. Infectious and parasitic diseases of captive passerines. Semin. Avian Exot. Pet Med. 12(1):21-28. <http://dx.doi.org/10.1053/ saep.2003.127878>

Jha P., Kim C.M., Kim D.M., Chung J.H., Yoon N.R., Jha B., Kim S.W., Jang S.J., Ahn Y.J., Chung J.K. \& Jeon D.Y. 2016. Transmission of Enterobacter aerogenes septicemia in healthcare workers. SpringerPlus 5(1):1-4. <http://dx.doi. org/10.1186/s40064-016-3011-x><PMid:27610316>

Kanashiro A.M.I., Castro A.G.M., Cardoso A.L.S.P., Tessari E.N.C. \& Tavechio A.T. 2002. Persistência de Salmonella sp. após antibioticoterapia em psitacídeos pertencentes a um criadouro comercial. Arqs Inst. Biológico, São Paulo, 69(2):99-101.
Kaper J.B., Nataro J.P. \& Mobley H.L. 2004. Pathogenic Escherichia coli. Nat. Rev. Microbiol. 2(2):123-140. <http://dx.doi.org/10.1038/nrmicro818> $<$ PMid:15040260>

Kirzinger M.W., Butz C.J. \& Stavrinides J. 2015. Inheritance of Pantoea Type III secretion systems through both vertical and horizontal transfer. Mol. Genet. Genomics 290(6):2075-2088. <http://dx.doi.org/10.1007/s00438015-1062-2><PMid:25982743>

Koneman E.W., Allen S.D., Janda W.M., Schreckenberger P.C. \& Winn W.C. 2001. Diagnóstico Microbiológico. $5^{\mathrm{a}}$ ed. Guanabara Koogan, Rio de Janeiro. 1608p.

Koneman E.W., Allen S.D., Janda W.M., Procop G., Schreckenberger P. \& Woods G. 2012. As Enterobacteriaceae, p.209-243. In: Koneman E.W. \& Winn W.C. (Eds), Diagnóstico Microbiológico: texto e atlas colorido. Guanabara Koogan, Rio de Janeiro.

Köse Ş., Özer E., Gülay Z., Akkoçlu G., Tokgöz H., Ağuş N., Ergönül Ö. \& Öztürk R. 2016. Enterobacter cloacae sepsis outbreak in neonatal intensive care unit due to contaminated total parenteral nutrition solution. J. Pediatr. Res. 3(2):109-112. <http://dx.doi.org/10.4274/jpr.20143>

Lima I.F.N., Quetz J.D.S., Guerrant R.L., Nataro J.P., Houpt E.R., Lima A.A.M. \& Havt A. 2013. Enteroaggregative Escherichia coli quantification in children stool samples using quantitative PCR. Apmis 121(7):643-651. <http:// dx.doi.org/10.1111/apm.12032><PMid:23216208>

Lynne A.M., Foley S.L. \& Nolan L.K. 2006. Immune response to recombinant Escherichia coli isso protein in poultry. Avian Dis. 50(2):273-276.<http:// dx.doi.org/10.1637/7441-092105R.1><PMid:16863080>

Lopes E.S., Maciel W.C., Teixeira R.S.C., Albuquerque Á.H., Vasconcelos R.H., Machado D.N. \& Santos I.C.L. 2016. Isolamento de Salmonella spp. e Escherichia coli de psittaciformes: relevância em saúde pública. Arqs Inst. Biológico, São Paulo, 83:1-10.

Macwhirter P. 1994. Passeriformes, p.1172-1199. In: Richie B.W., Harrison G.J. \& Harrison L.R. (Eds), Avian Medicine: principles and application. Wingers Publishing, Florida.

Madadgar O., Salehi T.Z., Ghafari M.M., Tamai I.A., Madani S.A. \& Yahyareyat R. 2009. Study of an unusual paratyphoid epornitic in canaries (Serinus canaria). Avian Pathol. 38(6):437-441.<http://dx.doi.org/10.1080/03079450903349170> <PMid:19937532>

Magiorakos A.P., Srinivasan A., Carey R.B., Carmeli Y., Falagas M.E., Giske C.G., Harbarth S., Hindler J.F., Kahlmeter G., Olsson-Liljequist B., Paterson D.L., Rice L.B., Stelling J., Struelens M.J., Vatopoulos A., Weber J.T. \& Monnet D.L. 2012. Multidrug-resistant, extensively drug-resistant and pandrug-resistant bacteria: an international expert proposal for interim standard definitions for acquired resistance. Clin. Microbiol. Infect. 18(3):268-281. <http:// dx.doi.org/10.1111/j.1469-0691.2011.03570.x><PMid:21793988>

Mantel M. 2005. A história do canário desde sua descoberta. Bras. Ornitol. $56: 8-9$.

Menezes E.A., Cezafar F.C., Andrade M.D.S.D.S., Rocha M.V.A.D.P. \& Cunha F.A. 2004. Freqüência de Serratia sp em infecções urinárias em pacientes internados na Santa Casa de Misericórdia de Fortaleza. Revta Soc. Bras. Med. Trop. 37(1):70-71.<http://dx.doi.org/10.1590/S0037-86822004000100020> $<$ PMid:15042191>

Mokady D., Gophna U. \& Ron E.Z. 2005. Extensive gene diversity in septicemia Escherichia coli strains. J. Clin. Microbiol. 43(1):66-73. <http://dx.doi. org/10.1128/JCM.43.1.66-73.2005><PMid:15634952>

Moulin-Schouleur M., Rèpèrant M., Laurent S., Brée A., Mignongrasteau S., Germon P., Rasschaert D. \& Schouler C. 2007. Extraintestinal pathogenic Escherichia coli strains of avian and human origin: link between phylogenetic relationships and common virulence patterns. J. Clin. Microbiol. 45(10):33663376. <http://dx.doi.org/10.1128/JCM.00037-07> <PMid:17652485>

Nascimento A.M., Cursino L., Gonçalves-Dornelas H., Reis A., Chartone-Souza E. \& Marini M.Â. 2003. Antibiotic-resistant Gram-negative bacteria in birds from the Brazilian Atlantic forest. Condor 105(2):358-361.<http://dx.doi. org/10.1650/0010-5422(2003)105[0358:AGBIBF]2.0.CO;2> 
Oliva-Menacho J.E., Garcia-Hjarles M.A., Oliva-Candela J.A. \& De la Cruz-Roca H.S. 2016. Contaminación con bacterias patógenas de estetoscopios del personal médico en un hospital de nivel III en Lima, Perú. Revta Med. Hered. 27(2):83-88. <http://dx.doi.org/10.20453/rmh.v27i2.2842>

Oliveira A.L., Rocha D.A., Finkler F., Moraes L.B., Barbieri N.L., Pavanelo D.B., Winkler C., Grassotti T.T., Brito K.C., Brito B.G. \& Horn F. 2015. Prevalence of ColV plasmid-linked genes and in vivo pathogenicity of avian strains of Escherichia coli. Foodborne Pathog. Dis. 12(8):679-685. <http://dx.doi. org/10.1089/fpd.2014.1934> <PMid:26258262>

Oliveira K.W., Gomes F.C.O. \& Morais P.B. 2012. Ocorrência de Escherichia coli multirresistentes a antimicrobianos nas principais praias do reservatório de Lajeado, TO. Eng. Amb. Pesq. Tecnol. 9(3):338-351.

Raidal S.R. 1998. Salmonellosis in two canary (Serinus canaria) flocks. Aust. Vet. Pract. 28(2):58-62.

Santos H.F., Flôres M.L., Lara V.M., Silva M.S., Battisti L. \& Lovato L.T. 2010. Microbiota cloacal aeróbia de cracídeos cativos no Rio Grande do Sul e sua susceptibilidade a antimicrobianos. Pesq. Vet. Bras. 30(12):1077-1082. <http://dx.doi.org/10.1590/S0100-736X2010001200013>

Sánchez-Cordón P.J., Gómez-Villamandos J.C., Gutiérrez J., Sierra M.A., Pedrera M. \& Bautista M.J. 2007. Atoxoplasma spp. infection in captive canaries (Serinus canaria). J. Vet. Med., Series A 54(1):23-26. <http://dx.doi org/10.1111/j.1439-0442.2007.00909.x><PMid:17359450>
Smith J.L., Fratamico P.M. \& Gunther N.W. 2007. Extraintestinal pathogenic Escherichia coli. Foodborne Pathog. Dis. 4(2):134-163. <http://dx.doi. org/10.1089/fpd.2007.0087><PMid:17600482>

Soncini R.A. 2002. Controle de Salmonella enteritidis na avicultura. Anais do III Simpósio Brasil Sul de Avicultura. Embrapa Suínos e Aves, Concórdia, SC. 6p.

Sousa E., Berchieri A.J., Pinto A.A., Machado R.Z., Carrasco A.O., Marciano J.A. \& Werther K. 2010. Prevalence of Salmonella spp. antibodies to Toxoplasma gondii, and Newcastle disease virus in feral pigeons (Columba livia) in the city of Jaboticabal, Brazil. J. Zoo Wildl. Med. 41(4):603-607. <http://dx.doi. org/10.1638/2008-0166.1><PMid:21370639>

Taniuchi M., Walters C.C., Gratz J., Maro A., Kumburu H., Serichantalergs O., Sethabutr O., Bodhidatta L., Kibiki G., Toney D.M., Berkeley L., Nataro J.P. \& Houpt E.R. 2012. Development of a multiplex polymerase chain reaction assay for diarrheagenic Escherichia coli and Shigella spp. and its evaluation on colonies, culture broths, and stool. Diagn. Microbiol. Infect. Dis. 73(2):121-128. <http://dx.doi.org/10.1016/j.diagmicrobio.2012.03.008> <PMid:22541788>

Tivendale K.A., Logue C.M., Kariyawasam S., Jordan D., Hussein A., Li G., Wannemuehler Y. \& Nolan L.K. 2010. Avian-pathogenic Escherichia coli strains are similar to neonatal meningitis E. coli strains and are able to cause meningitis in the rat model of human disease. Infect. Immun. 78(8):34123419. <http://dx.doi.org/10.1128/IAI.00347-10><PMid:20515929> 